\title{
Correction: Qualitative systematic reviews of treatment burden in stroke, heart failure and diabetes - Methodological challenges and solutions
}

Katie Gallacher ${ }^{1}$, Bhautesh Jani', Deborah Morrison ${ }^{1}$, Sara Macdonald ${ }^{1}$, David Blane ${ }^{1}$, Patricia Erwin ${ }^{2}$, Carl R May ${ }^{3}$, Victor M Montori ${ }^{2}$, David T Eton ${ }^{2}$, Fiona Smith ${ }^{1}$, G David Batty ${ }^{4}$, Frances S Mair ${ }^{1 *}$ and on behalf of the International Minimally Disruptive Medicine Workgroup

\section{Correction}

After publication of the original article [1] it came to the publishers attention that the name of author G David Batty had been inadvertently transposed. The correct authors' list should read as indicated above. We apologize for any inconvenience this has caused.

\section{Author details}

${ }^{1}$ University of Glasgow, Scotland, UK. ${ }^{2}$ Mayo Clinic, Rochester, MN, USA

${ }^{3}$ University of Southampton, England, UK. ${ }^{4}$ University College London, England, UK

Received: 11 December 2013 Accepted: 11 December 2013

Published: 10 January 2014

\section{Reference}

1. Gallacher K, Jani B, Morrison D, Macdonald S, Blane D, Erwin P, May CR, Montori VM, Eton DT, Smith F, Batty DG, Mair FS: International Minimally Disruptive Medicine Workgroup. Qualitative systematic reviews of treatment burden in stroke, heart failure and diabetes - Methodological challenges and solutions,. BMC Med Res Methodol 2013, 13:10.

\footnotetext{
* Correspondence: frances.mair@glasgow.ac.uk

'University of Glasgow, Scotland, UK

Full list of author information is available at the end of the article
}

\section{Submit your next manuscript to BioMed Central} and take full advantage of:

- Convenient online submission

- Thorough peer review

- No space constraints or color figure charges

- Immediate publication on acceptance

- Inclusion in PubMed, CAS, Scopus and Google Scholar

- Research which is freely available for redistribution 